\title{
Critical metals, provenance and palaeoclimate in the Upper Cretaceous Loodab bauxite deposit, Zagros Mountain, Iran
}

\author{
BATOUL TAGHIPOUR ${ }^{* 1}$, MASOUMEH TAHERI ${ }^{1}$ \\ ${ }^{1}$ Department of Earth Sciences, College of Sciences, Shiraz \\ University, Shiraz, Iran (*correspondence: \\ taghipour@shirazu.ac.ir, taheri.masume@gmail.com)
}

Bauxite deposits in Iran as a part of Iran-Himalayan belt bauxite deposits. The Kuh-e-Nil bauxite deposit is one of the known bauxite deposits in the Zagros folded and trust belt (ZFTB), which occurs as five distributed lenses in the Kuh-eNil anticline, $45 \mathrm{Km}$ northwest of the Dehdasht city. Bauxite formed through clay accumulation in the karst environment, "in situ" bauxitization and late formation of iron-rich concretions in a water-unsaturated pedogenic environment. The concretions, which are geochemical recorders of the environment of formation, have a large core of Al-hematite surrounded by a cortex of boehmite. Boehmite formed instead of Al-hematite at lower water activity values. The major element composition of the bauxite is dominated by elevated concentrations of $\mathrm{Al}_{2} \mathrm{O}_{3}, \mathrm{Fe}_{2} \mathrm{O}_{3}, \mathrm{SiO}_{2}$ and $\mathrm{TiO}_{2}$ and analyses of element mobility within the bauxite indicate that all elements except for $\mathrm{Cr}, \mathrm{Co}, \mathrm{Ni}, \mathrm{V}, \mathrm{Sc}, \mathrm{U}$ and $\mathrm{Th}$, and to a lesser extent LREE, are depleted relative to the immobile element Ti. Some low solubility elements (e.g., Th, Ti, V, Ga) were concentrated in detrital zircon and monazite ( $\mathrm{Zr}, \mathrm{Th})$, in anatase (Ti, V), and possibly in boehmite and hematite (Ga) during the later stages of bauxitisation. $\mathrm{Fe}$ and $\mathrm{Cr}$ were concentrated during wet conditions, whereas $\mathrm{Al}$ and $\mathrm{Co}$ accumulated during dry conditions [1]. Chondrite-normalized REE patterns can also be used to identify parent materials. The underlying limestone, shale and bauxite ores show similar chondrite normalized REE plots and negative $\mathrm{Eu}$ anomalies $\left(\mathrm{Eu} / \mathrm{Eu}^{*}\right)$ that imply the same provenance rocks. Furthermore, the $\sum$ LREE $(\mathrm{La}-\mathrm{Sm}) / \sum$ HREE $(\mathrm{Gd}-\mathrm{Lu})$ ratios in the bauxite samples are close to that of the underlying limestone. Geochemical data indicate the underlying limestone and the bauxite samples analyzed during this study have $\sum$ LREE/ $\sum$ HREE ratio values (ave. 6.5 and ave. 9.91; respectively) that are higher than those of the laterites derived from basic (1.9) and ultramafic (3.3) protolith [2]; however they are generally close to average upper continental crustal compositions (e.g., the $\sum$ LREE/ $\sum$ HREE value of PostArchean Australian shale is 9.4) [3].

[1] Mongelli et al. (2014) Ore Geol. Rev. 63, 9-21. [2] Ahmadnejad et al.(2017) Ore Geol. Rev. 86, 755-783. [3] MacLean \& Barrett (1993) J. Geochem. Explor. 48, 109-133. 